\title{
Social Citizenship, Social Policy and Refugee Integration: a Case of Policy Divergence in Scotland?
}

\author{
GARETH MULVEY \\ University of Glasgow, Glasgow G12 8QQ, United Kingdom \\ email: gareth.mulvey@glasgow.ac.uk
}

\begin{abstract}
The relationship between Holyrood and Westminster is an evolving one where there is some evidence of policy divergence. Underpinning policy approaches are different views of social citizenship, with the Holyrood approach maintaining elements of the post-1945 welfare settlement. The place of refugees and asylum seekers within these differing approaches is currently underexplored. This article looks at the Scottish and UK Governments' views of social rights and how they apply to asylum seekers and refugees. It suggests that despite refugee 'policy' being at least partly reserved, the Scottish Government has been able to take a different approach from that of Westminster, an approach underpinned by these differing welfare outlooks.
\end{abstract}

\section{Introduction}

The nature of the devolution settlement in the UK is evolving and there is evidence of differing philosophies underpinning social policy. These differences are also evident in asylum and refugee policy, despite elements of each being reserved. Immigration issues are transversal policy issues, crossing all levels of government, supra-national, national and sub-national/sub-state and local, and so are ideal policy areas in which to examine some of these differences. Within the devolved UK/Scottish context that this paper is based on, immigration policy - i.e. who is allowed into the country - is reserved to the UK Government but immigrant policy - i.e. what happens once they arrive - is largely devolved to the Scottish Government and its pre-2007 incarnation the Scottish Executive (see Hammar, 2006). While few policy areas are truly independent, there are some transversal policies that impact upon and are impacted by others more directly. Social exclusion policy in the UK has been analysed accordingly (Levitas, 2005) but immigrant policy has perhaps not been treated as such by policy-makers or researchers. The breadth of transversal policies means that they are also indicative of broader philosophies underpinning policy-making. Access to social rights 
inherent in much social policy is an important issue in terms of migrant settlement and broader debates about rights stratification and the welfare state. Thus far, the focus in terms of integration or settlement has been on national models, with little attention to variation within states (see the collection by Hepburn and Zapata-Berrero, 2014, for an exception). However, policy construction in immigrant policy, i.e. who has access to social goods, and deservedness and social citizenship can have territorial variance (see for example Koopmans and Statham, 1999; Meer, 2015).

There is an established link between social policy, social citizenship and devolution. Greer and Matzke (2009), for example, argue that devolutionary reforms change citizenship by changing the government that makes social citizenship rights real. 'Regional' variance in such social citizenship rights for one specific population group is the focus of this article. The aim is to look at a small area of policy as a means of highlighting different ideas underpinning social citizenship and access to rights. The article suggests that differing views of social citizenship between UK and Scottish Governments has led to different ideas about immigrant policy and practice and that these differences matter for the people concerned but are also indicative of a move away from UK models of immigrant policy.

The proxy concept for immigrant policy in this paper is integration. Integration in the UK covers a multitude of both reserved and devolved policy areas such as immigration policy, employment and welfare, national security, citizenship and naturalisation, and foreign affairs (all reserved); housing, education, health, community planning, neighbourhood policy, policing, and social work (all devolved); and justice which, in terms of the asylum system in Britain, is both reserved and devolved. Successive Scotland Acts maintain the principle that anything not specifically stated as being reserved becomes devolved. In essence the article suggests that differing views of social citizenship and the devolved settlement opened up space for sub-national policy discretion in an area that was seen as at least partly reserved to the UK Government. Its implications suggest a more malleable devolved settlement than is often thought, with differing and diverging beliefs regarding public services having an impact. The paper attempts to look comparatively at Holyrood and Westminster views of social citizenship by looking at refugees' access to social rights.

Refugees are the only migrant group in the UK to have had a specific integration policy. Despite the complexities of the devolved context, integration policy, from the perspective of the UK Government, has been Home Office driven so has usually applied to refugees throughout the UK. Thus Scottish policy in many cases has been additional.

This article begins by looking at the devolution settlement alongside social citizenship. It then goes on to examine the trajectory of refugee policy at the UK level, with the separation of the rights of asylum seekers from those of refugees 
a key issue that points towards rights stratification. The article then moves on to look at Scottish policy and how this is reflective of a differing approach to social citizenship. The discussion section begins by highlighting what divergent practices mean in terms of access to rights before making some suggestions as to its importance for the practice of refugee integration more generally. It concludes by pointing to the possibility of future comparative work based on differing philosophies in federal and quasi-federal states. How to describe the UK and Scotland as states is contested and there is not the space in this article to enter into such debates. Suffice to say that, despite its conceptual problems, both the UK and Scotland are viewed as nation states, with the latter going through a process of nation-building at present (Béland and Lecours, 2008; Kymlicka, 2011)

\section{Devolution and social citizenship}

The role of universality in social policy and social citizenship debates is one of the most important and longstanding in social policy (Béland et al., 2014). Marshall (1950: 8) defined social citizenship as the whole range from the right to a modicum of economic welfare and security to the right to share to the full in the social heritage and to live the life of a civilised being according to the standards prevailing in society'. Thus it links to both access to rights and the sharing in social goods in various forms of welfare capitalism (Esping-Andersen, 1990). Who has access to social rights changes and there appears to be divergence between the UK and Scottish governments on this matter, such that the UK Government has moved more towards rights stratification while the Scottish Government maintains some elements of universalism.

This article attempts to introduce two new dimensions to debates about social rights, social citizenship and migration. It focuses on differences in social citizenship within a nation state, that of the UK, and does so by attention to the most neglected migrant 'type', that of refugees. In looking at welfare regimes for this population, the devolved settlement is viewed as setting the parameters of rights but is also seen as malleable, allowing divergences to occur.

For Béland and Lecours (2008) divergence from the post-1945 welfare state consensus on the part of successive UK Governments has created a difference between Scottish and UK Governments' philosophies of welfare. They highlight the post-1945 consensus as a key factor in the creation of British identity and that the breakdown of this consensus contributed to divergence between Holyrood and Westminster. In a sense the move away from universalism in Westminster policy, with Holyrood holding more firmly to that principle, is a large part of social policy divergence and subsequent differing views on social citizenship (see Mooney and Scott, 2005: 7). Keating, for example, points to the relative imperviousness of service provision in Scotland to many New Public 
Management initiatives that have taken hold in the UK Government's welfare state responsibilities (2009: 113), though this should not be overstated. He adds that differences in provision of public services are often small but that they are also consistent in pointing to a different policy scope in Scotland where there remain remnants of universalism (ibid).

Social rights, however, straddle both devolved and reserved policy competencies.

For Mitchell (2009: 313) devolution was conceived of in dualist terms, specifically to allow different policies to develop in Holyrood from those in Westminster. However, the dominance of Westminster was in most cases assumed, largely due to control of overall finances through the block grant. That dominance partly explains the rarity of overt differences between Westminster and Holyrood in the early years of the Scottish Parliament. The additional factor was that the Labour Party were in power in both parliaments (see for example Keating, 2005), a so called party congruity.

That said, during the period of Labour being in office at the UK and Scottish levels of government, policy divergences did occur, some of which speak directly to issues of social citizenship. A universal approach was evident in care for the elderly, tuition fees and free prescription charges, all areas subject to restriction in England. This is suggestive of a different view of social citizenship within the Scottish polity more generally, as these differences emerged at a time when Labour and the Liberal Democrats were in power, but continued under the SNP. Some authors have also commented on the Scottish Executive's vow to end 'dawn raids' (early morning removal of asylum seekers whose asylum claims had been rejected) (Mooney and Williams, 2006) and the 'Fresh talent' initiative (Williams and De Lima, 2006) as a sign of a different approach to migration matters in Scotland. Fresh talent allowed international students graduating from Scottish universities to stay and work in Scotland for a defined period. However, the Westminster Government effectively integrated the policy into its points-based system for immigration in 2008. With regard to the former, the Labour-led Government in Scotland at the time was reluctant to enter into conflict with the UK Labour Government, meaning the regularity of dawn raids reduced but there was no official ending of such practices.

Actual policy divergence on migration issues has therefore been negligible. However, Cairney points out that policy-making both shapes and is shaped by the policy environment, meaning different things are taken into account in identifying problems and decisions as to how to address them (Cairney, 2012: 111). Spaces can therefore occur as a result of the Scottish Government either positively or negatively reacting to the agenda being set by the UK Government. This is also true in terms of the way that social policy is framed, with such framing pointing towards potential solutions. An example of this was Scottish policy-makers adopting the concept of social inclusion rather than Westminster's 
social exclusion, which is a means of highlighting structural causes of exclusion or lack of inclusion rather than solely individual agency (Béland and Lecours, 2008 133).

However, while different priorities can emerge at different levels of government within the same transversal policy, reserved powers can impact upon how devolved authorities use their powers. In Scotland, this is most notable in the block grant provided to the Scottish Government. The relationship between reserved social security policy and devolved social policy is instructive. To characterise things somewhat crudely regarding inclusion/exclusion, UK Government policy in some instances has created or contributed to the social exclusion of sections of the population. The results of this exclusion are then met by Scottish Government social policy, devolving penury (Mitchell, 2002) but also opening up space for policy divergence.

\section{The UK Government and refugee integration - a case of social rights stratification}

Integration was historically a concept largely avoided in Britain due to a perception of it being a form of assimilation, which conflicted with the multi-cultural approach being taken from the 1960s onwards (Castles, 2010). Nevertheless, multiculturalism/anti-racism. as an alternative to integration, was from then on predicated on a dual perspective: the external control of migrant numbers and the internal outlawing of racial discrimination (Solomos, 2003; Miles, 1993). One implication of the external plank was that migrants were seen as creating integration problems due simply to being here. This construction contained within it the solution to the perceived problem, i.e. restricting numbers. In addition, the internal plank never stretched to positive integration measures or affirmative action, just the outlawing of discrimination. In terms of broader integration, approaches reflecting its transversal nature have been largely absent. Only refugees in the 2000 sere subject to tangible and funded integration strategies, which have now ended. Such programmes when they did exist were predominantly the preserve of the Home Office with a UK wide remit, meaning that the Scottish Government has had a subsidiary role in what was considered a reserved policy matter.

Of huge importance to refugee integration is the UK Government approach since the early 1990 of of completely differentiating between refugees and asylum seekers, by which small numbers of resettled refugees are deemed wanted, and spontaneous arrivals in the form of asylum seekers are unwanted. At least part of the reason for this links to the dual approach of the 1960 s and rested on the controllability of such movements. Spontaneous movement challenged the external plank of race relations policy. The distinction has had the obvious impact of treating those in the asylum system differently from recognised refugees, a 
rights stratification and move away from any form of universalism. The British Government effectively takes the position that the integration of refugees is desirable but that asylum seekers should not be integrated until they have been recognised as refugees and, even then, the temporary status available to refugees can undermine integration (Stewart and Mulvey, 2014). Thus policy interventions where they have existed have been aimed solely at those who have had their claims for refugee status recognised. Asylum seekers, by comparison, have had many social rights removed through, for example, restrictions on access to healthcare, to education and even to ESOL classes. Indeed asylum seekers were removed from the social security system entirely by the creation of the National Asylum Support Service in the 1999 Immigration and Asylum Act, a symbolically important move with regard to social citizenship as it signified that asylum seekers were not deserving of access to mainstream social security. Add to this the removal of the right to work in 2001 and we see a series of restrictions on the ability of asylum seekers to access social goods and social rights. The last of these was justified on the basis of work acting as a pull factor for 'illegitimate' asylum claims (Robinson and Segrott, 2002; Mayblin, 2016), but the ramifications spread well beyond the asylum process into the period in which they have been recognised as refugees (Mulvey, 2015) with unemployment and/or underemployment the common end point.

In 2000 the Home Office developed its first refugee integration strategy, 'Full and Equal Citizens'. The stated aim was to help refugees access jobs, benefits, accommodation, health care, education and language classes, as well as encourage community participation. Rhetorically it was imbued with a social policy perspective that suggested integration as an outcome of access to social citizenship. Indeed the very title of the strategy suggests such an approach. It was established as a means of supporting small local projects rather than as a national strategy and it provided limited resources to organisations working with refugees. In its first year $\mathfrak{L}_{500,000}$ was available to new organisations with a further $\mathfrak{E} 650$, o0o to support capacity building among existing organisations. It also established a national integration forum to monitor the implementation of this strategy although, in reality, there was little to monitor. This forum was chaired by the Home Office, had representation from the voluntary sector, but had no sub-national presence despite both the crossover in policy competencies and the beginning of asylum dispersal in 2001. Glasgow was the only Scottish local authority to take part in dispersal and has taken roughly 10 per cent of all asylum applicants since then, meaning that no other single local authority in the UK has taken more asylum seekers (Mulvey, 2015).

In 2005 Full and Equal Citizens was superseded by Integration Matters, which included a funded national (UK) programme for the first time. The focus was on the labour market and on behavioural expectations of refugees. Thus it was imbued with an individualist tone congruent with the social policy approach of 
the New Labour Government. This strategy led to the establishment of the Sunrise programme in 2005. It offered individual, time-limited casework support to newly recognised refugees in relation to housing, employment, benefits and financial advice, access to English language tuition and information on the process of family reunion (Stewart, 2009). Sunrise was replaced by the Refugee Integration and Employment Service (RIES) in 2008 with a narrower but longer-term focus. RIES came out of the Labour Government's last refugee integration strategy, 'Moving on Together'. This document was primarily focussed on internal Home Office reform alongside 'innovations' in the asylum process. However, it also stated that 'our work helping refugees after they have been granted the right to stay in the UK has not often been in the foreground' (Home Office, 2009). RIES maintained the caseworker approach but was more limited in providing support in employment and education, as well as the opportunity to have a mentor. However, this support would last for a year rather than the previous 28 days.

While the costs of Sunrise are unclear, the total costs of RIES over four years was around $\mathfrak{E}_{25}$ million (Hansard, Jan 17, 2014 Col 721W). Spencer (2011: 216) calculates that less than 1 per cent of overall asylum and refugee spend went on integration. The Scottish share of this $\mathfrak{L}_{25}$ million is likely to be roughly $\mathfrak{E} 2.5$ million, given the proportion of UK asylum numbers dispersed to Glasgow.

Moving on Together reinforced UK Government support, with an emphasis on refugees integrating into the workplace although without sufficient recognition of the barriers being faced in trying to do so (Bloch, 2007). That is, the onus was entirely on refugees themselves, an approach that sat comfortably with Tony Blair's view that migrants have a 'duty to integrate' (BBC, 2006) and the approach to social exclusion more generally. There was a contradiction between an asylum policy that denied the right to work and a refugee policy that took an employability approach to supporting refugees into work, with the former having a negative impact on the latter. This is at least partly to do with deskilling during the asylum process (Bloch, 2007; Mulvey, 2015). However, since 2011, those in the asylum process in England are also unable to access language classes, further delaying employability. Furthermore, as Bloch (2007: 22) points out, the imposition of temporary refugee status in 2005 is likely to mitigate against education and training.

The Coalition Government elected in 2010 developed a somewhat different approach to refugee integration, although it has parallels with the early years of the Labour Government. In 2006, issues concerning race and faith had moved from the Home Office to the Department of Communities and Local Government (DCLG). Refugee integration had remained at the Home Office, primarily through the operation of RIES, which did not end until 2011. However, on the ending of RIES, responsibility for refugee integration also shifted to the DCLG (Rutter, 2015: 48), meaning that it applies to England only. This can be seen 
as a return to the days prior to the existence of national and funded integration programmes through Sunrise and RIES, when integration was viewed as an aspiration by documents such as Full and Equal Citizens but was largely unfunded. Nevertheless, it is worth looking at what the DCLG says about integration to gain a sense of the UK Government's direction of travel; this is especially important given the majority Conservative Government elected in 2015 and the belated agreement to resettle 20,000 Syrian refugees by 2020 .

The 2010 Coalition Government's plans were spelled out in the DCLG 'Creating the Conditions for Integration' (DCLG, 2012). In it the emphasis is on a minimal role for central government and a clear position on what will and what will not be supported. It states that 'Government will only act exceptionally' and that 'only small amounts of funding' will be available, with the expectation that action 'will rapidly become self-sustaining'. Any funded initiatives are for broader communities or localities; there are no initiatives with the specific aim of integrating migrants in general, never mind refugees in particular. The document talks of mainstream services having more of an impact than specific new integration activity but, given this was taking place in the context of austerity, these mainstream services were also being rationalised. The language of localism and of enterprise joins a key strategic goal of combatting extremism to set the parameters of government plans, such that even policies such as free schools are mentioned as a means of assisting integrated communities (DCLG, 2012: 15).

Although Government programmes were always somewhat limited, they did at least provide some financial and strategic support to the integration of refugees. Asylum support is paid at just 70 per cent of income support levels, and that shortfall had previously been paid as a lump sum to those recognised as refugees. This practice was replaced by the introduction of integration loans.

These loans, and some support to local authorities taking part in Gateway resettlement and Syrian resettlement, are the only UK Government support to integration today. Gateway refugees are recognised as such by UNHCR while still outside of the UK and are controlled and therefore less unwanted. The UK Government currently takes around 750 resettled refugees each year, although they say they will resettle 20, ooo Syrian refugees between 2015 and 2020.

Other aspects of integration have not been addressed by specific policy interventions but have, in some cases, been caught up within broader policy debates such as those around community cohesion, social inclusion/exclusion and wider immigration policy. These are joined by numerous social policy issues such as those around education as well as broader austerity measures that all head in the direction of rationalisation and stratification. It is in some of these social policy areas that successive Scottish Governments have developed their approach. 


\section{Access to social citizenship? Scottish government policy on refugee integration}

Keating (2009) and Béland and Lecours (2008) point to the broad resilience of universalism in Scottish social policy, in contrast to the movement towards selective support and rights stratification in Westminster. In essence the devolved settlement means that issues around those rights that are not specifically reserved in the Scotland Acts effectively become devolved. Thus while the devolved settlement means that the Scottish Government has no jurisdiction over immigration, many integration matters are addressed through access to rights in devolved social policy. This is of particular importance given that the 2016 Scotland Act devolves more social policy. This clearly makes such social policy issues less of a distinct refugee integration policy but does hint at a different set of principles underlying the approach. It is the exclusion of asylum seekers and refugees from social access in England set against their partial inclusion in Scotland that has created divergence and suggests a more universal approach in Scotland. In a sense refugee integration in Scotland has always been more mainstreamed. This is reflected in the fact that core responsibility for refugee issues now lies with 'Social Justice, Communities and Pensioner Rights', having previously been with the Minister for 'External Affairs and International Development' but led by the Equality Unit. The closest equivalent to the Home Office in Scotland is Justice. With jurisdiction over the courts and the police it, like the Home Office, has a control and protect agenda. However, this type of security-based approach has had no locus in migration issues in Scotland.

The Scottish government, including its predecessor the Scottish Executive, always took a symbolically different approach from that of the UK Government with regard to both the general discourse around migration, as well as more specific refugee integration issues. Even when Labour was in power at both levels of government, the approach diverged. A symbolic but important example is that all administrations, since the establishment of the Scottish Parliament in 1999, have operated on the basis that, where they have powers to do so, integration should begin the day an asylum seeker arrives in Scotland under the Home Office dispersal scheme. Thus Scottish policy makers take the position that, beyond the specified reserved powers that set the rules for the asylum process, they will use what power they have to encourage and facilitate the integration of asylum seekers, not just refugees.

However, due to the reserved nature of immigration and the Home Office's control of refugee integration strategies, refugees in Scotland were also subject to integration support through Sunrise and RIES. As already mentioned regarding RIES, this amounted to around $\mathfrak{E}_{2} .5$ million over four years. It is difficult to ascertain all additional resources spent on various integration measures either directly, through funding organisations and/or services, or via payments made 
to the local authority. However, it is clear that money beyond Sunrise and RIES has been spent. In parliamentary questions, for example, the Labour-dominated Scottish Executive highlighted that they had allocated $\mathfrak{E} 9$ million to aid refugee integration between 2001 and 2004, the first three years of asylum dispersal. Although the level of expenditure after 2004 is not as easy to ascertain, in 2013 the Scottish Government stated that $\mathfrak{E} 13.5$ million had been spent on refugee integration since 2001 (Scottish Government, 2013). There has, in fact, been remarkable continuity in the approach of successive Scottish governments to refugee integration.

Looking at more specific social policy areas is also instructive in a comparative sense. While not solely focussed on refugees, ESOL funding forms a major part of the Scottish Government's approach and contrasts with that of the UK Government. Free language support for asylum seekers in England ended in 2011 when such support was tied to 'actively seeking work'. This is a status denied to those in the asylum process. However, no such restrictions were placed on access to ESOL for asylum seekers in Scotland. Indeed the Scottish Government is explicit in contrasting its approach to that of the UK Government (Scottish Government, 2013).

There has also been provision around extra support for asylum seekers to pursue educational courses (up to 16 hours a week in Further Education) and educational support for children in asylum-seeking families. If they have been in Scotland for three years, they get the same access to schools as all other children. In addition, all of those in the asylum process get the same access to further and higher education after three years in the country regardless of the progress of their case, a position perhaps threatened by the most recent Immigration Act (2016) (see Celcis, 2016). There was also work done between the Scottish Government and Glasgow City Council in providing nursery places for asylum-seeking families. For those whose asylum claim has been refused, the Scottish Government argues for continued access to primary health care, unlike in England, although operationalising this often relies on individual GP surgeries.

More recently, the Scottish Government has had a three-year integration strategy that ran between 2013 and 2016 and emerged from a large consultation with voluntary, statutory and refugee organisations. There is political commitment on the need for renewal and a consultation is underway about the form a renewed strategy will take. Integration from day 1 remains a key theme, alongside six individual action plans aimed primarily at better coordination to produce better outcomes for asylum seekers and refugees. Each action plan is led by various Government departments and statutory agencies (Scottish Government, 2013). It will be important to monitor any progress resulting from this strategy, although its very existence makes a contrast with the UK Government. 


\section{Discussion and Conclusions}

\section{The framing of migration, welfare and rights}

Diverging views of welfare and social citizenship between Holyrood and Westminster are apparent in a number of areas of policy. While much of this divergence is due to Westminster moving away from the post-1945 welfare consensus (Béland and Lecours, 2008; Keating, 2009) the on-going importance of the principle of universalism in Scotland is also evident and largely extends to various migrant populations. Divergence has occurred both formally, in terms of what competencies are devolved, and informally in the form of venue shift, particularly regarding access to the welfare state. There is a growing literature suggesting a problematic relationship between migrants and minority populations and the welfare state, perhaps beginning with the work of Putnam (2000) and, in the UK, Goodhart (2004). However, recently, more 'optimistic' accounts include Kremer's (2016) suggestion that solidarity and the welfare state shape each other and, as such, solidarity or cohesion is linked to access to social goods. This suggests that a more universalist approach can facilitate cohesion. This proposition is empirically tested by Andrews and Jilke (2016) who find a positive relationship between the quality of social services and social cohesion, while Shutes (2016) looks at how work-related welfare conditionality restricts the rights of non-nationals in the UK, and points to a move away from universalism at the UK level.

Such arguments matter when thinking of the Scottish Government's perspective on migration and social policy. Kymlicka argues that there is an explicitly multicultural Scottish nation building project underway. It is multicultural at least in part due to the fact that the Scottish government has committed itself to including immigrants within its conception of Scottishness' (2011: 294). If immigrants can make claims to Scottishness as Kymlicka suggests, then the implication is that they can also make claims in terms of the right to access social goods, a situation that diverges from the Westminster case. Scott and Wright (2012: 260) also suggest that discussions around social policy options in the devolved context are conducted as a debate about core principles, values and identities. 'Social policy has a crucial role to play in nation building' and this 'appears to have particular potency in the Scottish context'. Thus social policy is more closely linked to Scotland's self-understanding as a nation.

As has been suggested, divergence and a degree of autonomy have already happened in this policy area, despite the constitutional set-up appearing to limit the opportunity for different approaches. A different emphasis has been evident from the beginning of devolution in terms of both policy and underlying philosophy. The UK Government emphasises rights stratification and individualisation while the Scottish Government maintain some focus on structures and universalism although, as with the 1945 settlement, this universalism was not absolute (see Williams, 1992, for a feminist critique). 
The UK and Scottish governments see the purpose of migration differently, with the UK Government seeing migration as a means of filling short-term labour market gaps and/or as a potential threat and the Scottish Government looking for population and economic growth (Kyambi, 2009: 6). One suggests temporary or circular migration and the other settlement, leading to quite different approaches in relation to defining the issue. Indeed Hepburn and Rosie (2014: 256) suggest that the positive way in which migration is framed in Scotland bucks the overall trend in Europe of immigration restriction. That is, the way migration has been framed in Scotland is as a series of relatively unproblematic processes. Indeed the problems are often viewed as resulting from UK policy-making rather than migration itself.

In some ways the UK perspective on migration is a return to the 1960 s consensus that the presence of migrants is essentially what causes issues with regard to integration, though without the attendant welfarist approach of that period. A different approach is evident in Scotland and, when allied to UK Government withdrawal from refugee integration, this left a vacuum into which the Scottish Government could step. Together with further devolution, and with Scottish independence back on the agenda as a result of Brexit, the political incentive for both governments would appear to point to further divergence. That is, it seems unlikely that differences in the framing of migration or in terms of the philosophies of welfare between the two governments will coalesce. In terms of migration, the outcome of the Brexit vote and government responses to it suggest a likely widening of differences. The Theresa May Government appears to be pushing for some form of hard Brexit, accepting lack of access to markets in return for no or limited free movement. The Scottish Government, on the other hand, has taken a much more 'migrant friendly' approach (see for example Nicola Sturgeon's speech, BBC, 2016) that maintains the UK approach of the late 1990 and early 200os, viewing migration as something to be encouraged largely on the basis of the migrants' putative economic value (Geddes, 2005). Alongside this 'competitive nationalism' (Law and Mooney, 2012) is a more humanitarian approach to refugees, evident in the Scottish Government's narrative around the Syrian refugee 'crisis'.

\section{Devolved and reserved integration policy-making}

Spencer (2011: 19) states that, despite more cross-departmental working in UK government generally, 'on migration, the dominance of the Home Office has limited the influence of other departments and agencies keenly affected by it'. What is more, the Home Office during the late 1990s and 200os accumulated more power and influence, for example, in taking powers over the Seasonal Agricultural Workers Scheme from the Department for Rural Affairs, work permits from the Department of Employment and international students from the Department 
for Education. For Spencer (ibid 20) 'each element of migration policy is isolated from the mainstream economic and social policies that it affects, and is affected by. No effective governance arrangement has been established to address that gap, nor the equally problematic isolation from the devolved administrations and local services'. Thus migration was governed by a single UK Government department with a security agenda, and with limited interaction with others within the UK context and even less with the devolved authorities. However, despite or perhaps because of this limited interaction, alongside aspects of immigrant policy moving to England-only departments, space was created for policy divergence. These differences emerge from different fundamental ideas about the welfare state and the place of migrants within it.

It was devolution itself that created space for policy divergence. McEwan et al. (2012) point to a general preference for bilateral contact even in the context of differing governing parties. This becomes more difficult in transversal policy areas such as immigration and immigrant policy where policy at the UK level is developed by a UK wide department in some areas but England-only departments in others. Meanwhile, at the Scottish level, they have been in the scope of the cross-departmental Equality Unit, alongside External Affairs and International Development and, most recently, Social Justice, Communities and Pensioner Rights. The question arises therefore; with whom would bilateral talks take place in refugee issues even if there were a desire to have them? Not only is there an asymmetry in UK territorial structures but policy-making departments are also asymmetric.

Therefore, while immigration and asylum in a broad sense remains a reserved policy area under the devolution settlement, this does not mean that all aspects of the lives of asylum seekers and refugees are reserved. Classic areas of social policy and many factors that are important for social citizenship are devolved. Housing for asylum seekers, for example, is provided by the UK Government under contract to agencies but must also meet minimum housing standards set by the Scottish Government. On being recognised as a refugee, devolved housing policy and practice takes over entirely where, for example, different rules on the need for a 'local connection' to access social housing impacts upon access to accommodation and to broader mobility. The issue of local connection in Scotland is indicative of a different approach covering, as it does, any population who do not choose their location, such as prisoners. Nevertheless, it is the inclusion of asylum seekers within this area of social policy that matters.

The asylum process is reserved, and with it decisions on the right to work. However, the opening up of limited educational opportunities and some investment in the recognition of skills and qualifications, as well as some reskilling, suggests that the experiences of asylum seekers in that process also have elements of devolved policy. That said, there is nothing in the devolved settlement 
that prevents the Scottish Government from increasing access to education. Thus it is a constrained form of universalism that is evident.

Nevertheless, it is the use of existing autonomy and different approaches to the welfare state arising from the complexity of the devolved situation that can have an impact. There has been little evidence of policy competencies clashing, meaning that each Government within limitations has operated largely independently. This should not necessarily come as a surprise. Cairney and McGarvey (2013: 193) suggest that the logic of devolution leads the UK Government to general disengagement in policy areas associated with the Scottish Government and, with most social policy devolved, it has shown a limited desire to interfere in the operation of those policy domains. Thus, to return to the issues of social citizenship, this perhaps marginal policy area does interact with wider social policy. As Béland and Lecours (Béland and Lecours, 2008: 143) suggest, 'the impact of sub-state nationalism on social policy seems to have meant, at least in Scotland, more rather than less social protection', i.e. protection available to more rather than fewer people.

\section{Wider application of findings? - devolution and immigrant integration in EU}

While this case is instructive about the nature of devolution in the UK, it also has utility further afield. Schmidtke (2014: 77) states that 'cities and regions have become important laboratories for deliberating, developing, and implementing immigration and, in particular, integration policies'. There are examples of regional governments having different and diverging integration policies (see Hepburn and Zapata-Barrero, 2014). Some of these divergences are based on pragmatism, some on differing views of social citizenship and some on vacuums created by the lack of central policy. Arguably the Scottish case exhibits elements of each.

Some sub-national immigrant policy differences are highlighted by Schmidtke and Zaslove (2014) in North-Rhine Westphalia and Emilia-Romagna. They found that sub-national governments in each created divergence in both policy and practice as a result of two simultaneous developments, the politicisation of migration at the central level and growing space for difference at the regional level (Schmidtke and Zaslove, 2014: 4). Politicisation does not necessarily mean policy activism. Despite central government populism, Campomori and Caponio (2014: 130) suggest that, in the case of Italy, given the absence of any central policy, there was a policy vacuum for regions to step into. Of some relevance to Scotland, this allowed Italian regions to informally move into this area, before the reform of the Italian state in 2001 assigned complete social policy autonomy to the regions, 'thus acknowledging a de facto regional responsibility with regard to migrant integration' (ibid 131). 
In Emilia-Romagna, the sub-national authority used social policy measures to implement 'migrant aware' practices, leading to a 2004 integration law, subsequently used as a model for other regional authorities (Schmidke and Zaslove, 2014: 9). One of the explanatory factors in both cases is the different political cultures at the national and the regional levels: the national largely populist and restrictive and the regional more pragmatic and informed by dayto-day issues in local communities. Again there appear to be parallels with the case of Scotland with more access to social goods and social citizenship informed by these day-to-day concerns.

For these differences in approach to happen, however, requires political will on the part of the sub-state authority and some level of willingness on the part of the central state to allow, or at least not actively prevent, such developments. While there are therefore no direct comparisons for this case in the sense of providing a range of similarities, due at least in part to the idiosyncratic nature of the UK state, there are aspects of many other constitutional and political developments that exhibit crossovers.

Therefore, in policy fields exemplified by political contention (Koopmans and Statham, 2000), agenda setting can vary in different policy contexts, setting differential parameters of policy. That is, the way an issue is defined as a problem, or not, has an impact on the trajectory of policy in that area. However, it is important to look below the level of established nation states to do this. This suggests that the 'national models' of both integration and 'welfare capitalism' (Esping-Andersen 1990) need to be more nuanced in order to accommodate internal differences in approach and also need to relate more closely to one another.

\section{Acknowledgements}

I would like to thank the two anonymous reviewers and the editors for their helpful comments. I would also like to thank Gerry Mooney and Fergus McNeil for their comments on an earlier draft.

\section{References}

Andrews, R. and Jilke, S. (2016), 'Welfare States and Social Cohesion in Europe: Does Social Service Quality Matter?' Journal of Social Policy, 45, 1, 119-140.

BBC (2006), Conform to our society, says PM http://news.bbc.co.uk/1/hi/uk_politics/6219626. stm [accessed 5.5.2014].

BBC (2016), Brexit vote: Nicola Sturgeon statement in full http://www.bbc.co.uk/ news/uk-scotland-36620375 [accessed 15.11.2016].

Béland, D. and Lecours, A. (2008), Nationalism and Social Policy: The Politics of Territorial Solidarity Oxford University Press UK

Béland, D., Blomqvist, P., Andersen, J. G., Palme, J. and Wadden, A. (2014), 'The Universal Decline of Universality? Social Policy Change in Canada, Denmark, Sweden and the UK' Social Policy and Administration 48, 7, 739-756. 
Bloch, A. (2007), 'Refugees in the UK labour market: The conflict between economic integration and policy-led labour market restriction' Journal of Social Policy Vol 37 21-36.

Cairney, P. (2012), 'Intergovernmental relations in Scotland: What was the SNP Effect?' British Journal of Politics and International Relations Vol 14 231-249.

Cairney, P. and McGarvey, N. (2013), Scottish Politics (2nd edition) Palgrave MacMillan UK.

Campomori, F. and Caponio, T. (2014), 'Migrant Reception Policies in a Multilevel System: Framing and Implementation Structures in the Italian Regions' in E. Hepburn and R. Zapata-Barrero, (eds) The politics of immigration in multi-level states; governance and political parties Basingstoke Palgrave Macmillan, 130-149.

Castles, S. (2010), How nation-states respond to immigration and ethnic diversity Journal of Ethnic and Migration Studies 21, 3, 293-308.

Celcis Briefing (2016), https://www.celcis.org/news/news-pages/implications-immigration-bill2015-2016/.

Department of Communities and Local Government (2012), 'Creating the conditions for a more integrated society', London, Department of Communities and Local Government https://www.gov.uk/government/publications/creating-the-conditions-for-a-moreintegrated-society Crown Copyright [accessed 05.05.2014].

Esping-Andersen, G. (1990), The Three Worlds of Welfare Capitalism Princeton University Press New Jersey

Geddes, A. (2005), 'Europe's Border Relationships and International Migration Relations' Journal of Common Market Studies 43:4, 787-806.

Goodhart, D. (2004), Too Diverse? Prospect Magazine http://www.prospectmagazine. co.uk/magazine/too-diverse-david-goodhart-multiculturalism-britain-immigrationglobalisation.

Greer, S. L. and Matzke, M. (2009), 'Introduction; Devolution and Citizenship Rights' in S. Greer (Ed) Devolution and Social Citizenship in the UK Bristol Policy Press .

Hammar, T. (2006), 'European Immigration Policy: A Comparative Study' in A M Messina and G Lahav (Eds) The Migration Reader; Exploring Politics and Policies Boulder: Lynne Rienner Publishers

Hepburn, E. and Rosie, M. (2014), 'Immigration, Nationalism and Political Parties in Scotland' in the Italian Regions' in E Hepburn, and R Zapata-Barrero, (eds) The politics of immigration in multi-level states; governance and political parties, Basingstoke: Palgrave Macmillan, 241-260.

Hepburn, E. and Zapata-Barrero, R. (2014), The politics of immigration in multi-level states; governance and political parties, Basingstoke: Palgrave Macmillan.

Home Office (2000), Full and Equal Citizens A Strategy for the Integration of Refugees into the United Kingdom, Croydon: Home Office Crown Copyright.

Home Office (2005), 'Integration Matters a national strategy for refugee integration', Croydon: Home Office Crown Copyright [accessed 01.04.2009];

Home Office (2009), 'Moving on Together: Government's recommitment to supporting Refugees', Croydon, Crown Copyright [accessed 05.05.2014];

Keating, M. (2005), 'Policy Divergence and Convergence in Scotland under Devolution' Regional Studies 39, 4, 453-463.

Keating, M. (2009), 'Social Citizenship, Solidarity and Welfare in Regionalized and Plurinational States' Citizenship Studies 13, 5, 501-513.

Koopmans, R. and Statham, P. (1999), 'Challenging the Liberal Nation-State? Postnationalism, Multiculturalism, and the Collective Claims Making of Migrants and Ethnic Minorities in Britain and Germany', American Journal of Sociology 105:3, 652-696.

Koopmans, R. and Statham, P. (2000), 'Migration and Ethnic relations as a field of political contention: An opportunity structure approach' in R Koopmans, and P Statham, (Eds) Challenging immigration and ethnic relations politics: Comparative European perspectives Oxford: Oxford University Press

Kremer, M. (2016), 'Earned Citizenship: Labour migrants views on the Welfare State' Journal of Social Policy 45:3, 395-415. 
Kyambi, S. (2009), 'Room for manoeuvre? The options for addressing immigration-policy divergence between Holyrood and Westminster' Equality and Human Rights Commission Glasgow https://www.equalityhumanrights.com/en/file/5266/download?token=3DAF7-V828.

Kymlicka, W. (2011), 'Multicultural citizenship within multination states.' Ethnicities, 11, 3, 281-302.

Law, A. and Mooney, G. (2012), Competitive Nationalism: State, Class, and the Forms of Capital in Devolved Scotland Environment and Planning C 30:1, 62-77.

Levitas, R. A. (2005), The Inclusive Society? Social Exclusion and New Labour Basingstoke: Palgrave Macmillan.

Marshall, T. H. (1950), 'Citizenship and social class and other essays' Cambridge, Cambridge University Press.

Mayblin, L. (2016), Complexity reduction and policy consensus: Asylum seekers, the right to work, and the 'pull factor' thesis in the UK context The British Journal of Politics and International Relations 18, 4, 812-828.

McEwan, N., Swenden, W. and Bolleyer, N. (2012), 'Governments in Opposition? Intergovernmental Relations in the UK in a Context of Party Political Incongruence' British Journal of Politics and International Relations 14, 2, 187-343

Meer, N. (2015), 'Looking up in Scotland? Multinationalism, multiculturalism and political elites' Ethnic And Racial Studies 38, 9, 1477-1496.

Miles, R. (1993), 'Racism after 'race relations' London: Routledge

Mitchell, J. (2002), 'Towards a New Constitutional Settlement?' in C Hay (ed) British Politics Today Cambridge, Polity Press 237-258.

Mitchell, J. (2009), Devolution in the United Kingdom, Manchester, Manchester University Press

Mooney, G. and Scott, G. (2005), 'Introduction' in G Mooney and G Scott (Eds) 'Exploring Social Policy in the 'New Scotland', Bristol, The Policy Press.

Mooney, G. and Williams, C. (2006), 'Forging new 'ways of life'? Social policy and nation building in devolved Scotland and Wales' Critical Social Policy 26:3, P 608-629.

Mooney, G., Croall, H., Munro, M. and Scott, G. (2015), 'Scottish criminal justice: Devolution, divergence and distinctiveness' Criminology and Criminal Justice, 15, 2, 205-224.

Mulvey, G. (2015), 'Refugee integration policy: the effects of UK policy-making on refugees in Scotland' Journal of Social Policy, 44, 2, 357-375

Putnam, R. D. (2000), Bowling Alone: The Collapse and Revival of American Community New York, Simon \& Schuster.

Robinson, V. and Sergott, J. (2002), 'Understanding the decision making of asylum seekers' Home Office research study 243, London, Home Office [accessed 17.08.2009].

Rutter, J. (2015), 'Moving Up and Getting On; Migration, Integration and Social Cohesion in the UK' Bristol Policy Press

Schmidtke, O. (2014), 'Beyond national models: Governing migration and integration at the regional and local levels in Canada and Germany 'Comparative Migration Studies, 2, 1, 77-99.

Schmidtke, O. and Zaslove, A. (2014), 'Why regions matter in immigrant integration policies: North Rhine-Westphalia and Emilia-Romagna in comparative perspective' Journal of Ethnic and Migration Studies, 40, 12, 1854-1874.

Shutes, I. (2016), 'Work-related Conditionality and the Access to Social Benefits of National Citizens, EU and Non-EU Citizens' Journal of Social Policy 45, 4, 691-707.

Scott, G. and Wright, S. (2012), 'Devolution, social democratic visions and policy reality in Scotland' Critical Social Policy 32, 3, 440-453.

Scottish Government (2013), 'New Scots: Integrating Refugees in Scotland's Communities', Edinburgh, Scottish Government http://www.scotland.gov.uk/Publications/2013/12/4581

Scottish Government (2014), 'More powers for the Scottish parliament; Scottish Government Proposals', Edinburgh, Scottish Government http://www.scotland.gov.uk/Resource/ 0046/00460563.pdf.

Solomos, J. (2003), Race and Racism in Britain Basingstoke, Basingstoke, Palgrave MacMillan Spencer, S. (2011), The Migration debate Bristol, Policy Press 
Stewart, E. (2009), 'New issues in refugee research: the integration and onward migration of refugees in Scotland: a review of the evidence' Discussion paper. United Nations High Commissioner for Refugees, Switzerland http://strathprints.strath.ac.uk/16585/

Stewart, E. and Mulvey, G. (2014), 'Seeking safety beyond refuge: the impact of immigration and citizenship policy upon refugees in the UK' Journal of Ethnic and Migration Studies 40, 7, 1023-1039.

Williams, C. and De Lima, P. (2006), 'Devolution, multicultural citizenship and race equality: From laissez-faire to nationally responsible policies' Critical Social Policy 26, 3, 498-522.

Williams, C. and Mooney, G. (2008), 'Decentring Social Policy? Devolution and the Discipline of Social Policy: A Commentary' Journal of Social Policy, 37, 3, 489-507.

Williams, F. (1992), 'Somewhere over the Rainbow: Universality and Diversity in Social Policy' in Social Policy Review Vol 4 200-219. 